\title{
Mobile Banking Service Quality and Customer Retention: A Moderated Mediation Model of Customer Perceived Value and Perceived Corporate Image
}

\author{
Daniel Kipkirui Langat ${ }^{*}$, Dr. Ronald Bonuke ${ }^{2}$, Dr. Yusuf Kibet ${ }^{3}$ \\ 1,2,3 Moi University, Kenya \\ * Corresponding author: dlangat09@gmail.com
}

\begin{abstract}
Article History
Received 2021-06-25

Revised 2021-07-18

Accepted 2021-07-19

Published 2021-07-20
\end{abstract}

\section{Keywords \\ Mobile Banking Service Quality \\ Customer Perceived V alue \\ Perceived Corporate Image \\ Customer Retention \\ Kenyan Banking Industry}

\section{How to cite?}

Langat, D. K., Bonuke, R., \& Kibet, Y. (2021). Mobile Banking Service Quality and Customer Retention in the Kenyan Banking Industry: A Moderated Mediation Model of Customer Perceived $V$ alue and Perceived Corporate Image. SEISENSE Journal of Management, 4(4), 47-61.

doi:10.33215/sjom.v4i4.672

Copyright (C) 2021 The Author(s) (cc) BY

\section{Abstract}

Purpose- This study examined the moderating effect of perceived corporate image on the indirect relationship between mobile banking service quality and customer retention via customer perceived value in the Kenyan banking industry

Design/Methodology- The study adopted an explanatory research design, employing multistage, simple random and systematic sampling techniques in collecting data from a sample size of 400 consumers of mobile banking services in Kenya using a selfadministered questionnaire

Findings- The results reveal a significant mediating effect of customer perceived value on the relationship between mobile banking service quality and customer retention. Moreover, the study established that perceived corporate image moderates the relationship between; mobile banking service quality and customer perceived value and mobile banking service quality and customer retention. Finally, perceived corporate image moderates the indirect link between mobile banking service quality and customer retention via customer retention at all levels

Practical Implications- These findings underscore the need for the bank's management and policymakers to develop quality assurance policies and devise value-centered strategies and image-enhancing strategies to enhance customer retention.

Originality/Value - The study's findings bring new critical knowledge concerning the indirect effect of customer perceived value and perceived corporate image on the study variables. 


\section{Introduction}

Customer retention is increasingly becoming an essential managerial issue, especially in this era characterized by high levels of competition and assertive customers who make stay or switch decisions guided by their rational and emotional influences. Moreover, customers are quality conscious, value-driven, and get attracted by strong and positive corporate images. As technology becomes the order of the day and new development in the economy creates new opportunities that are hard to assume, many organizations are looking for ways to embrace technology to survive. Mobile banking services can raise efficiency and boost business growth through cheap, efficient, and reliable money service support systems that reduce the need for cash transactions and the risks associated (Rahman et al., 2017).

Since the inception of M-banking, the Kenyan banking sector has witnessed tremendous changes. Customers now have access to fast, efficient, and convenient banking services. Most of the Kenyan banks are now investing large sums of money in mobile banking technology. However, while the rapid development of mobile banking technology has made some banking tasks more efficient and cheaper, technological advancements have their fair share of problems that may compromise the quality of service, such as; restructuring challenges, customer reluctance and cost challenges, system failure, network vulnerabilities, software defects and operating mistakes, processing error and data loss due to virus among others. If unchecked, these challenges pause threats to the whole idea behind mobile banking service technology (Manali, 2014). Therefore, it is essential to initiate a discourse on whether mobile banking service quality matters in influencing customer retention in the Kenyan banking industry.

Customer retention has attracted significant interest from scholars and practitioners in relationship marketing in the past decade. For example, studies have established that it is better to retain existing customers than recruit new ones. Alshurideh, (2016) established that the cost of acquiring each new mobile subscriber was estimated at between $\$ 600.00$ and $\$ 800.00$, which encompasses many costs such as advertising, marketing, sales, and commissions. Hence, it is beneficial for service providers to establish a relationship with customers they would like to retain. This broadly supports earlier findings by Woisetschläger et al., (2011), who established that customer retention is an important managerial issue for service provider organizations because it is associated with an increase in the organization's revenue and reduction in cost. Studies have shown that the retention of existing customers plays a key role in cost reduction. Lax, (2016), reported that the cost of servicing existing customers is lower than the cost of managing new customers. This is because most of the cost of servicing new customers is fixed, while there are additional costs such as onboarding-related costs specifically incurred because of new customers. He noted that even after incurring these costs, half of these new customers may leave within the first 90 days of becoming customers of the bank

Literature also reflects the relationship between corporate image and perceived quality of products/services and customer perceived image. Some researchers consider corporate image an antecedent to perceived quality and value, whereas others take the opposite view. For instance, it has been argued that corporate image significantly affects perceived quality and precedes consumer evaluations, rather than the evaluations being components of the image (Ladhari, Ladhari, et al., 2011). While some studies have established some mediating relationships between these constructs (Al-Hawari, 2006; Al-Hawari et al., 2009; Kaur \& Soch, 2013), little has been done to establish the moderating role of corporate image on the relationship between mobile banking service quality and perceived customer value. Hence this study seeks to fill this gap.

The relationships between mobile banking service quality and customer retention have been tested (MoyoTalak, 2013; Surendra, 2015; Tamuliene \& Gabryte, 2014), customer perceived value and customer retention have also been tested (Angel Moliner Tena et al., 2006; Cronin et al., 2000a; Evans, 2002), there seems to be little or no published research testing the mediating effects of customer perceived value on the relationship between mobile 
service quality and customer retention. Therefore, this study examines the relationship between mobile banking service quality and customer retention and how perceived customer value mediates the relationship between mobile banking service quality and customer retention among Kenya's commercial banks.

The assessments of many studies on banking have been fragmented when evaluating the exact nature of the relationships. To date, there is limited evidence of studies that investigated the effects of mobile banking service quality, customer perceived value, perceived corporate image and customer retention constructs in a single framework or tested the relationships simultaneously. Thus, the complex interrelationships among these constructs have not been fully discovered and understood for the banking sector and, from a Kenyan perspective. This study seeks to understand further the interrelationships and their effects on customer and hence, how can be improved.

\section{Literature Review}

\section{Mediating Role of Customer Perceived Value}

Customer perceived value has been studied as a consequence of service quality and the antecedent of customer retention in multiple past investigations. Hapsari et al. (2016) are among the recent researchers who established a positive and significant relationship between service quality and perceived value. Past studies have also established that customer perceived value is a trigger of customer retention. Parasuraman \& Grewal (2000) established that perceived value is the most important predictor of repeat purchase intention. Moreover, extant literature indicates that customer perceived value is a common construct between the quality of service and customer retention (Chen \& Zhu, 2012; Hanaysha, 2018; Keshavarz \& Jamshidi, 2018). The mediating role of customer perceived value on the relationship between service quality and customer retention is summed up by the argument by Hapsari et al. (2016) that consumer perceptions of the inherent characteristics of banking service quality can help to reinforce favorable brand associations that eventually lead to long-lasting customer commitment towards a firm's banking services. Based on the enumerated importance of customer perceived value, we can conclude that mobile banking service quality directly affects customer perceived value, influencing customer retention.

\section{Moderating Role of Perceived Corporate Image}

Corporate image is an impression of a firm over the minds of customers/public, which can be formed through a comparison of innumerable firm-related attributes (Gautam, 2011). Research has underscored that corporate image plays an important role in strengthening the relationships between perceived quality, value, and customer retention. According to Hapsari et al. (2016), service quality drives customers' perceived value. Still, this relationship is stronger where the customer's perception of the firm's corporate image is favorable or weaker where the customer's perception of value is low. Rabach and Tarus (2013) also established that a favorable company image enhances the relationship between service quality and customer satisfaction, social pressure, and customer loyalty. In their study on the effects of customer relationship management on Customer Satisfaction and Loyalty in China, (Chung et al., 2015) confirmed that indeed corporate image plays a moderating role in both of these relationships.

\section{Study Hypotheses}

The main objective of this work was to examine the moderating effect of perceived corporate image on the indirect relationship between mobile banking service quality and customer retention via customer perceived value in the Kenyan banking industry. We hypothesized that;

$\mathbf{H}_{01}$ : Customer perceived value mediates the relationship between mobile banking service quality and customer retention 
$\mathbf{H}_{02}$ : Perceived corporate image moderates the relationship between mobile banking service quality and customer perceived value.

$\mathbf{H}_{03}$ : Perceived corporate image moderates the relationship between mobile banking service quality and customer retention

$\mathbf{H}_{04}$ : Perceived corporate image moderates the relationship between customer perceived value and customer retention

$\mathbf{H}_{05}$ : Perceived corporate image moderates the indirect relationship between mobile banking service quality and customer retention via customer perceived value.

It is also based on the above discussion that we propose Figure 1 as the conceptual model of the study

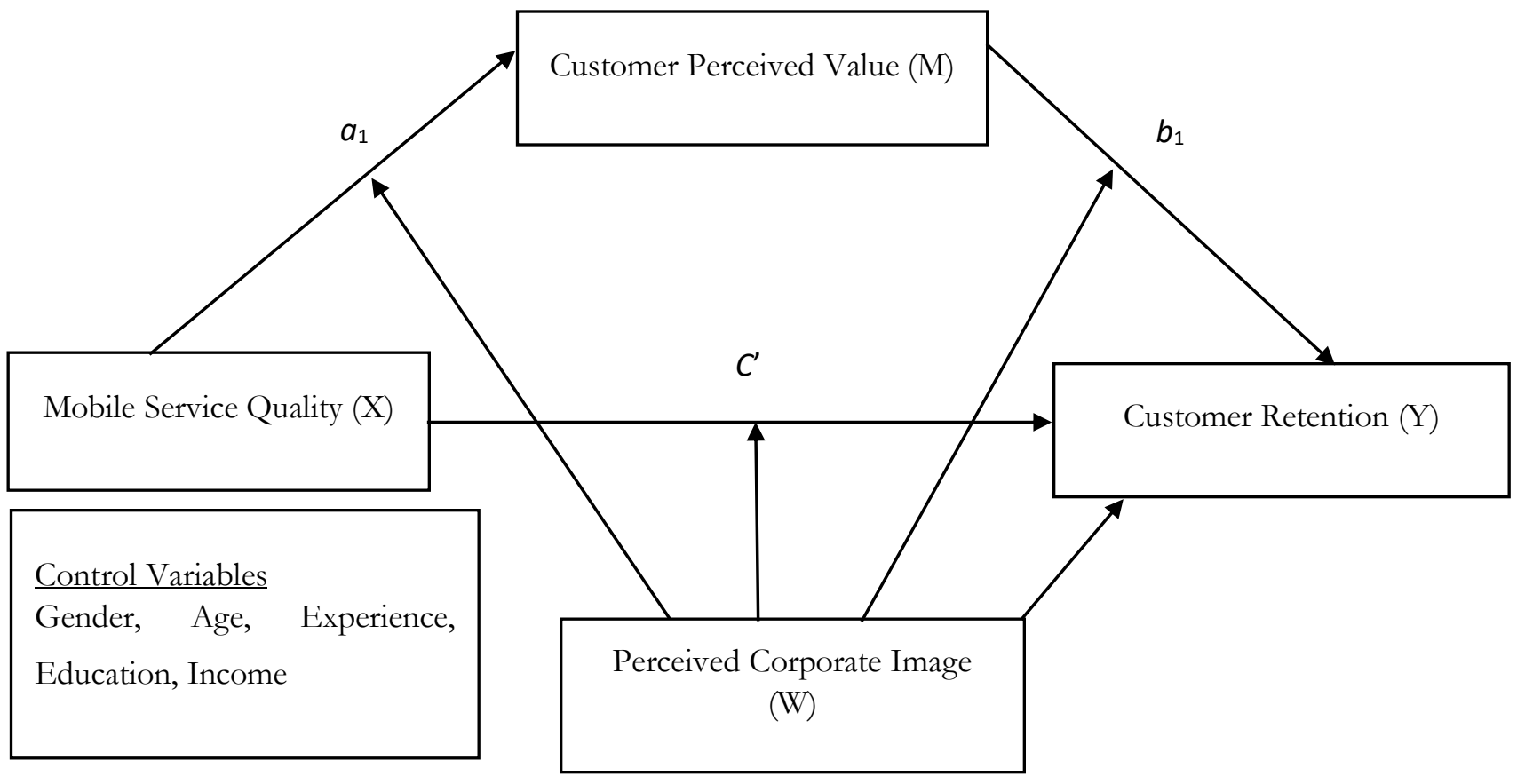

Figure 1 - Conceptual Model

\section{Measurement}

\section{Customer Retention}

Customer retention refers to the propensity of a mobile banking service customer to stay with their bank for the foreseeable future. Each question was assessed on a five-point Likert-type scale with anchors "1=strongly disagree" and "5=strongly agree". The variable had three items adapted from (Siu et al., 2013). The three questions in the questionnaire are; I intent will re-patronize my bank's mobile banking services for the foreseeable future, I would recommend my bank's mobile banking services to my relatives and friends, and I intend to increase the usage of the various mobile banking services offered by my bank. 


\section{Mobile Banking Service Quality}

This variable was measured using seventeen items adapted from (Surendra (2015) with modifications to suit the study. The questions were assessed on a five-point Likert-type scale with anchors " $1=$ strongly disagree" and " $5=$ strongly agree". The seventeen questions were; My bank's Mobile banking system is always available for use, My bank's Mobile banking system operates smoothly, and without delays, My bank's Mobile banking system does not crash, The bank quickly resolves mobile banking related problems, I obtain accurate and errorfree service from my bank's mobile banking services, I feel safe using my bank's mobile banking services, Risk associated with my bank's mobile banking services is low, Personal information exchanged over mobile banking services is not misused by my bank, I feel secure in providing sensitive information during mobile banking transactions, My bank's Mobile banking services are prompt hence, it takes shorter waiting time, My bank's Mobile banking services are prompt hence, it takes shorter waiting time, My bank's mobile banking Services saves my time.

\section{Customer Perceived Value}

All the questions were assessed on a five-point Likert-type scale with anchors " $1=$ strongly disagree" and "5=strongly agree". Customer perceived value was measured using five items adapted from (Yang \& Peterson, 2004). The five items include; Continuous innovations to mobile banking service makes me feel good, I get good value from the mobile banking services for a reasonable price, I don't mind sacrificing time and efforts to access and use mobile banking services, Compared with other bank services such ATM, it is wise to choose this mobile banking services and, I believe that mobile banking services are designed with customer's best interests at heart.

\section{Measurement of Perceived Corporate Image}

The perceived corporate image was measured with eight items adapted from (Nguyen \& Leblanc, 2001). The questions were assessed on a five-point Likert-type scale with anchors " $1=$ strongly disagree" and " $5=$ strongly agree" The eight items were; My bank is innovative and pioneering, My bank has a good reputation, My bank has a better image than its competitors, My bank ethically does its business, My bank is open and responsive to consumers, My bank contributes to the society, In my opinion, my bank has a good image in the minds of its customers, and Overall, I have a good impression of my Bank.

\section{Covariates}

The study controlled gender, age, experience, education level, and income of the customer to eliminate their adverse influence on mobile banking service quality, customer perceived value, and customer retention. Gender was measured as either 'Male' or 'Female,' age was measured as '18-25 years', '26-35years', '36-45 years', '46-55 years', '56-65 years' and 'above 66 years, the customer experience was measured based on the duration of being a customer as 'below 1 year', '1-5years', '5-10 years' and 'above 10 years' and education level was measured at 'Primary Certificate', 'Secondary Certificate', 'Diploma holder', 'Undergraduate degree', 'Master's Degree' and 'PhD holder' and income level was measured as 'less than Kshs. 9,999', 'Kshs. 10,000- Kshs.50, 000' 'Kshs. 51,000- Kshs.99, 999' and 'above Kshs. 100,000'

\section{Research Methodology}

An explanatory research design was adopted in collecting data from consumers of mobile banking services, drawn from two public and two private universities in the Republic of Kenya. Data was collected from a sample size of 400 respondents randomly selected from a target population of 3958 using a self-administered, closedended questionnaire between June 4th and 21st 2019. 
A multistage sampling technique was employed in this study. The first stage was the choice of study location; Nairobi County was purposively chosen based on the fact that it is Kenya's capital city and most of the banks' headquarters are domiciled in the county and the fact that a greater number of public and private universities (23 out of 46) are located in Nairobi county (uniRank ${ }^{\mathrm{TM}}, 2020$ ). The second stage was the choice of the universities to draw respondents from. The Universities were clustered into two; public and private, where four (4) universities were randomly selected; two (2) from public universities and two (2) from private universities based on the list of Commission for University Education Accredited Universities - November 2017. The third stage was the choice of a university staff who formed the study's unit of analysis. Systematic sampling was then employed, allowing every $\mathrm{K}^{\text {th }}$ element in the population to be sampled, beginning with a random start of the element in the range of 1 to $\mathrm{K}$. Then, finally, the respondents' consent was sought to participate in the study before administering the questionnaire.

Table 1- Target Population and Sample Size

\begin{tabular}{clccc}
\hline S no & Name of the University & $\begin{array}{c}\text { Target } \\
\text { population }\end{array}$ & Percentage & $\begin{array}{c}\text { Proportionate } \\
\text { sample size }\end{array}$ \\
\hline 1 & $\begin{array}{l}\text { Kenyatta University (KU) } \\
\text { The Co-operative University of Kenya } \\
\text { (CUK) }\end{array}$ & 3000 & 76 & 303 \\
2 & Catholic University of East Africa & 280 & 7 & 28 \\
3 & (CUEA) & 450 & 11 & 46 \\
4 & Africa Nazarene University & 228 & 6 & 23 \\
& TOTAL & $\mathbf{3 9 5 8}$ & $\mathbf{1 0 0}$ & $\mathbf{4 0 0}$ \\
\hline
\end{tabular}

\section{Results}

\section{Response Rate and Demographic Profile of Respondents}

Four Hundred (400) questionnaires were issued to the respondents, only 332 were filled and returned, but only 326 questionnaires were used since they were correctly filled. In comparison, six (6) questionnaires that were partially filled were excluded from the analysis. The overall survey response rate was $81 \%$, while the nonresponse rate was $19 \%$. Table 2 indicates the summary of the respondents' demographic characteristics, which shows that $54.0 \%(\mathrm{~N}=176)$ were male and $46.0 \%(\mathrm{~N}=150)$ were female. The majority of the respondents $(43.9 \%, \mathrm{~N}=143)$ were of ages $26-35$, and the least were those aged above 60 years $(\mathrm{N}=12)$, representing $3.7 \%$. The demographic characteristics also revealed that most respondents were undergraduate Degree holders (46.3\%, N= 151), while the minority were Ph.D. holders (4.6\%, N=12). Moreover, the statistics show that most respondents $(39.0 \%, \mathrm{~N}=127)$ have been customers of the bank for between $5-10$ years, while the least were those who have been customers of the bank for less than 1 year $(\mathrm{N}=19)$, representing 5.8\%. Lastly, the statistics indicate that a majority of the respondents had their income ranging from between Khs. 10,000 Khs.50, $999(36.8 \%, N=120)$, and the income ranges for a minority of the respondents $(\mathrm{N}=120)$, was less than Khs. 9,999 representing $(18.0 \%$,

\section{Descriptive Statistics}

Table 2 displays the means, standard deviations, reliability, and correlation results for all research variables. The findings indicate that customer retention had the highest mean of 4.016 with a standard deviation of .610. In contrast, mobile banking service quality had the lowest mean of 3.860 and a standard deviation of 0.592 . Additionally, the scale reliability was in the accepted range as the Cronbach' Alpha was above .7 for all variables. Furthermore, results of correlation show that all variables were positively associated with customer retention 
with mobile banking service quality having the highest relationship with $\mathrm{r}=.569, \mathrm{p}<.01$, followed by customer perceived value with $\mathrm{r}=.536, \mathrm{p}<.01$, while Perceived Corporate Image had the weakest but positive association with $\mathrm{r}=.246 \mathrm{p}<.01$.

Table 2 - Means, Standard deviations, Reliability, and Correlation Results

\begin{tabular}{llllllll}
\hline Name of Variable & Mean & SD & Reliability & Correlation1 & $\mathbf{2}$ & $\mathbf{3}$ & $\mathbf{4}$ \\
\hline Customer Retention & 4.016 & 0.610 & 0.762 & - & & & \\
Mobile Service Quality & 3.860 & 0.592 & 0.714 & $.569 * *$ & - & & \\
Customer Perceived Value & 3.974 & 0.642 & 0.701 & $.559^{* *}$ & $.536^{* *}$ & - & \\
Perceived Corporate Image & 3.864 & 0.780 & 0.847 & $.311^{* *}$ & $.261^{* *}$ & $.246^{* *}$ & - \\
\hline
\end{tabular}

** Correlation is significant at $p<.01$ (2-tailed)

\section{Testing for Mediation}

A mediation test was conducted to assess the mediating effect of customer perceived value on the relationship between Mobile banking service quality and customer retention in the Kenyan banking industry. This study adapted (MacKinnon et al., 2012) four-step procedure in testing for mediation.

1. The effect of mobile banking service quality on customer perceived value indicated as path "a ${ }_{1}$ " (Figure 1)

2. The effect of customer perceived value on customer retention, path "b," (Figure 1).

3. The effect of mobile banking service quality on customer retention while controlling for customer perceived value, path C' of Figure 1.

4. Finally, the indirect path between mobile banking service quality and customer retention via customer perceived value $\left(a_{1} \times b_{1}\right)$. Covariates (gender, age, experience, education, and income) were included in the analysis.

In the first step, as shown in Table 3 (model 1), mobile service quality was found to significantly affect Customer perceived value $(\beta=0.532, \mathrm{p}=0.000)$. The model explains $29 \%$ of the variance while all the covariates were found to be insignificant. In the second step, customer perceived value was found to have a significant effect on customer retention, $\beta=0.363, \mathrm{p}=0.000$ (Table 3 Model 2). Moreover, the same Model 2 (Table 3) was used to test for the third step while controlling customer perceived value. The study established that mobile banking service was found to have a significant effect on customer retention with $\beta=0.372, \mathrm{p}=0.000$. In this model, too, all the covariates were found to be insignificant. This model accounted for $41.1 \%$ of the variance.

Finally, the results show that the mean indirect effect from the bias-corrected percentile bootstrap analysis (Model 3, Table 3) indicate that the indirect effect of mobile banking service quality on customer retention via customer perceived value was significant, $\mathrm{a}_{1} \times \mathrm{b}_{1}=.532 \times .363=.193, \mathrm{SE}=.036, \mathrm{CI}=.127,266$. We established that both path " $a_{1}$ " and " $b_{1}$ " of the conceptual framework are significant, hence, a partial mediation between mobile banking service quality on customer retention via customer perceived value. Furthermore, Model 4 (Table 3) reveals the total effect (Direct + Indirect) $=.372+.193=.565$ was found to be significant as indicated by $\beta=0.565, p=0.000$. This finding established that the total effect model accounts for $31.7 \%$ of the total variance in customer retention. Results further show that all the covariate effects were not significant. Based on the above results, Hypothesis 1 was supported by the study findings. 
Table 3 - The Indirect Effect of Mobile Banking Service Quality on Customer Retention via Customerperceived value

\begin{tabular}{lllllll}
\hline Variables & Model 1 $(\mathrm{CPV})$ & \multicolumn{3}{c}{ Model 2 $(\mathrm{CR})$} & \multicolumn{2}{l}{ Model 3 (Total Effect) } \\
\hline & $\beta$ & $p-v$ & $\beta$ & $p-v$ & $\mathrm{~B}$ & $p-v$ \\
\hline Constant & -.062 & .834 & .024 & .929 & .002 & .996 \\
Gender & .057 & .557 & -.018 & .842 & .003 & .974 \\
Age & .050 & .370 & .018 & .720 & .036 & .505 \\
Experience & -.012 & .850 & -.030 & .600 & -.035 & .577 \\
Education & -.035 & .597 & .058 & .338 & .045 & .487 \\
Income & .012 & .872 & -.069 & .290 & -.065 & .355 \\
MobSQ & $.532^{* * *}$ & .000 & $C^{\prime}=.372^{* * *}$ & .000 & $.565^{* * *}$ & .000 \\
CustPerV & - & - & $b_{1}=.363^{* * *}$ & .000 & - & - \\
\hline $\mathrm{R}^{2}$ & .290 & & .411 & & .317 & \\
$\mathrm{~F}$ & $21.683^{* * *}$ & & $31.580^{* * *}$ & & $24.611^{* * *}$ \\
\hline Mediation & $=\mathrm{a}_{1} \times \mathrm{b}_{1}=.532 \times .363$ & $=.193, \mathrm{SE}=036$ & $\mathrm{CI}=.127, .266$ \\
\hline
\end{tabular}

\section{Testing for Moderation}

The research also hypothesized that perceived corporate image moderates mobile banking quality, customer perceived value, and customer retention. Results from the conditional process analysis using Hayes (2018) PROCESS macro vs3.2, (Model 59) are presented in Table 4

In the first multiple regression, we sought to establish whether perceived corporate image moderates the relationship between mobile banking service quality and customer perceived value (shown as path $a_{1}$ in Figure 1). The results as shown in (Table 4 , Model 1$)$ reveal that mobile service quality $(\beta=.485 \mathrm{p}=.000)$ and perceived corporate image $(\beta=.146, \mathrm{p}=.005)$ were both found to have a positive significant influence on customer perceived value. Most importantly, the interaction results indicate existence of moderation $(\beta=-.091, \mathrm{p}=.039)$. We controlled for gender, age, experience, education, and income. Results indicate that all the covariates were non-significant in this model. The findings show that the model has $\mathrm{R}^{2} .312$, which implies that this model explains $31.2 \%$ of the variance in this model. This means that when the image of a bank is high, service quality would significantly affect customer perceived value.

Table 4 - Moderation Results of PCI on the Study Variables

\begin{tabular}{|c|c|c|c|c|}
\hline Variable & Model 1 (Customer Perceived Value) & \multicolumn{3}{|c|}{ Model 2 (Customer Retention) } \\
\hline & $\beta$ & $\mathrm{p}-\mathrm{V}$ & $\mathrm{B}$ & $\mathrm{p}-\mathrm{v}$ \\
\hline Constant & -.045 & .877 & .041 & .877 \\
\hline Gender & .053 & .580 & -.034 & .700 \\
\hline Age & .068 & .218 & .025 & .613 \\
\hline Experience & -.023 & .713 & -.036 & .526 \\
\hline Education & -.030 & .653 & .060 & .316 \\
\hline Income & .004 & .960 & -.071 & .265 \\
\hline MSQ & $.485^{* * *}$ & .000 & $.347 * * *$ & .000 \\
\hline CPV & - & - & $.337 * * *$ & .000 \\
\hline PCI & $.146^{* *}$ & .005 & $.167 * * *$ & .000 \\
\hline MSQ $\times$ PCI & $-.091 *$ & .039 & $-.112^{*}$ & .032 \\
\hline $\mathrm{CPV} \times \mathrm{PCI}$ & - & - & $.139 * *$ & .007 \\
\hline $\mathrm{R}^{2}$ & .312 & & & \\
\hline $\mathrm{F}$ & $17.887 * * *$ & & 24.9 & \\
\hline
\end{tabular}

Note: ${ }^{*} p<.05,{ }^{* *} p<.01,{ }^{* * *} p<.001, \mathrm{MSQ}=$ Mobile Service Quality, CPV $=$ Customer Perceived Value, PCI= Perceived Corporate Image, MSQ $\times$ PCI and CPV $\times$ PCI $=$ moderation effect 
The finding of this interaction is further illustrated by Figure 2, which reveals that the slope of the mobile banking service quality and customer perceived value is positive under a strong corporate image both customers with low and high perceptions of corporate image. This, in essence, means that a favorable corporate image enhances the relationship between mobile banking service quality and customer perceived value. Based on these findings, Hypothesis $\mathrm{H}_{2}$ is supported.

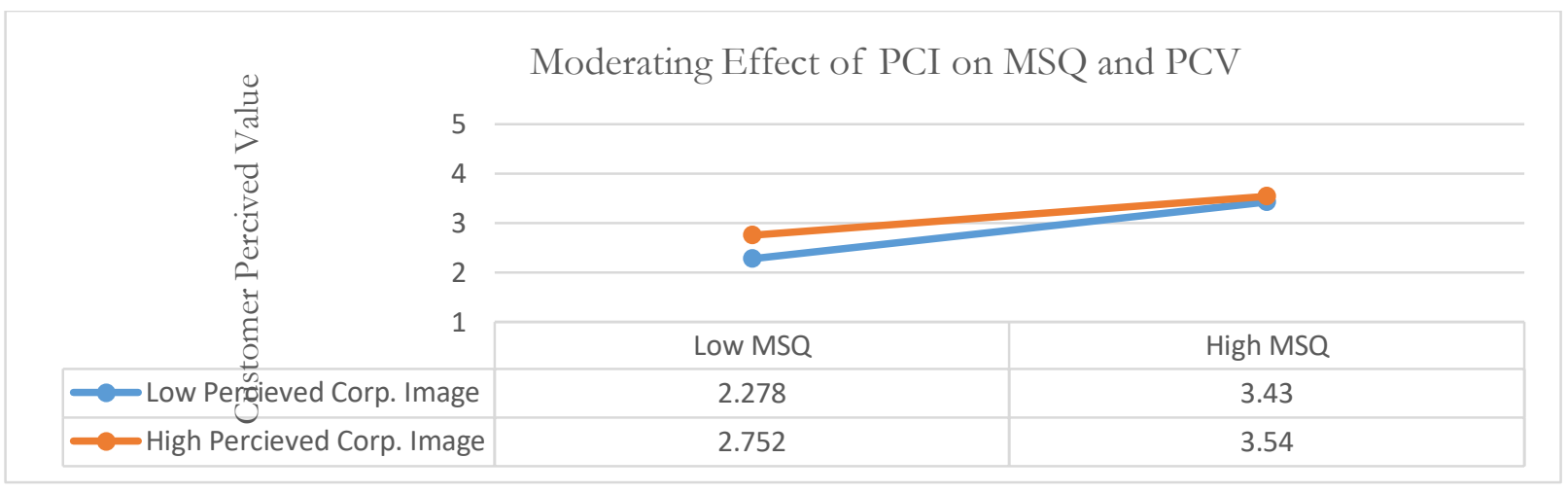

Figure 2 - Moderating Effect of Perceived Corporate Image on Mobile banking Service Quality and Perceived Customer Value

Secondly, we tested to establish whether perceived corporate image moderates the path from mobile banking service quality to customer retention (path $C$ in Figure 1). The outcome in (Table 4, Model 2 ) shows that mobile service quality $(\beta=.347, \mathrm{p}=.000)$, customer perceived value $(\beta=.337, \mathrm{p}=.000)$, and perceived corporate image $(\beta=.167, \mathrm{p}=.000)$ were all found to have a positive and a significant influence on customer retention in the model. In addition, results indicate that the interaction of perceived corporate image on the relationship between mobile banking service quality and customer retention was significant, as shown by $\beta=-.112, \mathrm{p}=$ .032. The R2 for the second regression model .443, implying that $44.3 \%$ of the variance in customer retention could be accounted for by the model. This means that when a bank's image is high, mobile banking service quality would significantly enhance customer retention.

The finding of this interaction is further illustrated by Figure 3, which reveals that the slope of the mobile banking service quality and customer retention is positive under a favorable corporate image for both customers with low and high perceptions of corporate image. This implies that a strong corporate image enhances the relationship between the customer perceived value and customer retention. Based on these findings, Hypothesis $\mathrm{H}_{3}$ is supported.

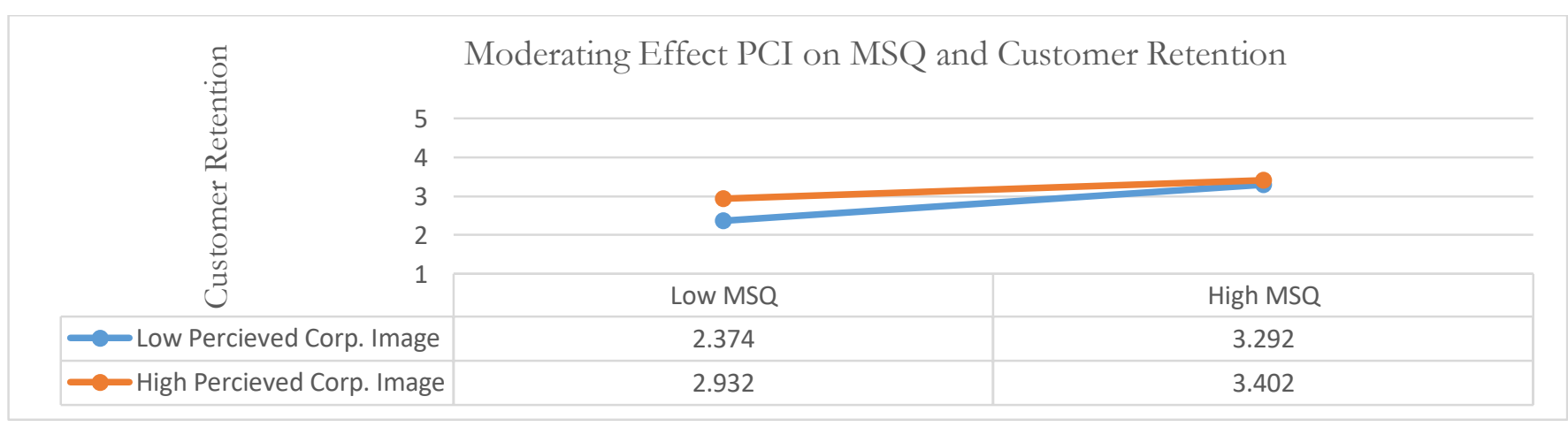

Figure 3 - Moderating effect of perceived corporate image on mobile banking service quality and perceived value

Thirdly, we tested whether the perceived corporate image has a moderating effect on the relationship between customer perceived value and customer retention. This was tested in the same Model 2 of Table 4. All control 
variables were included in the analysis, and none was found significant. Findings indicate that the interaction effect of perceived corporate image on the relationship between customer perceived value and customer retention is positive and significant, as shown by $\beta=.139, \mathrm{p}=0.007$. This means that when the image of a bank is high, customer perceived value would have a significant effect on customer retention.

The finding of this interaction is further illustrated by Figure 3 which reveals that, the slope of the customer perceived value and customer retention is positive under a favourable corporate image both customers with low and high perceptions of corporate image. This implies that a strong corporate image enhances the relationship between the customer perceived value and customer retention. Based on these findings, Hypothesis $\mathrm{H}_{4}$ is supported.

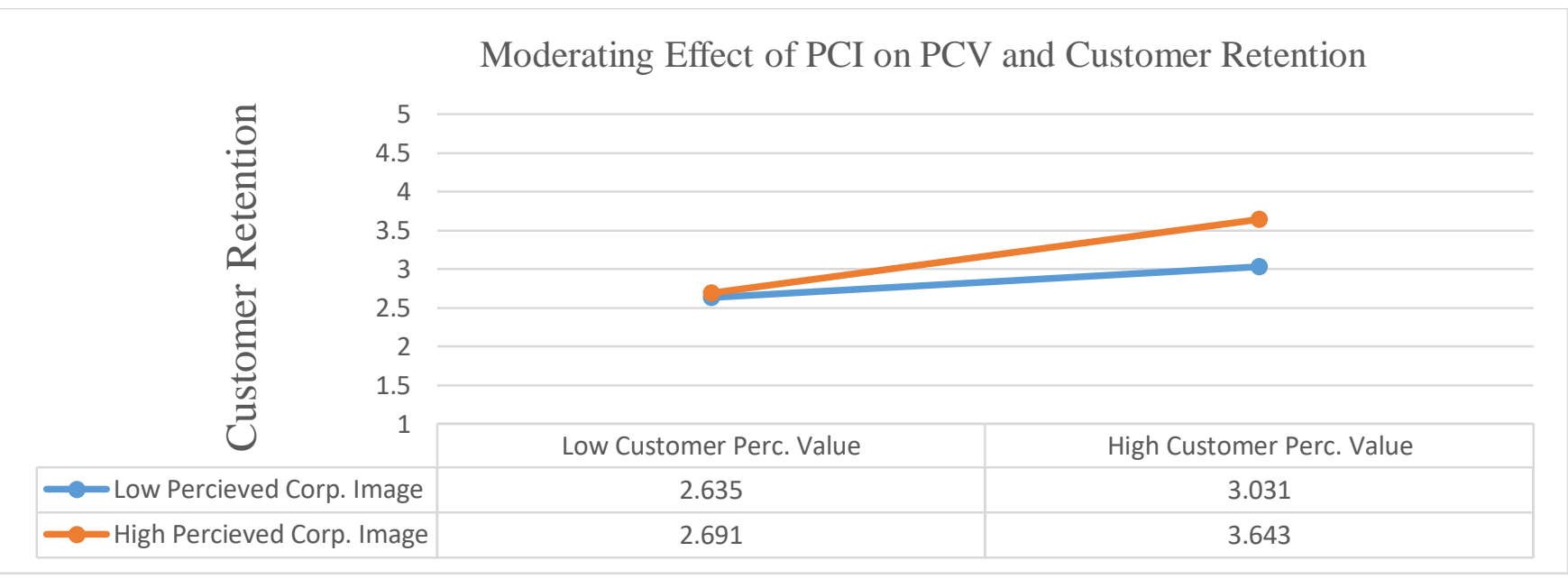

Figure 4 - Moderating Effect of Perceived Corporate Image on Perceived Customer value and Customer Retention

Finally, in hypothesis $\mathrm{H}_{4}$, we postulated that perceived corporate image moderates the indirect relationship between mobile banking service quality and customer retention through customer perceived value. To test for this hypothesis, data probing was done at three levels of the moderator (perceived corporate image); at 1 standard deviation below the mean, at the mean level and at 1 standard deviation above the mean, as shown in table 6.

Table 5 - Conditional process analysis of the indirect effects of perceived corporate image

\begin{tabular}{lllll}
\hline & Effect & SE & LLCI & ULCI \\
\hline Low perceived corporate image (-1 SD) & .114 & .050 & .024 & .224 \\
Mean perceived corporate image (mean = 0) & .163 & .036 & .100 & .240 \\
High perceived corporate image (+ SD) & .187 & .051 & .100 & .296 \\
\hline
\end{tabular}

The results of the test, as shown in Table 6 indicate that the moderated mediation happened between mobile banking service quality and customer retention via customer perceived value at all the three levels of perceived corporate image (low-level $\mathrm{b}=.114, \mathrm{CI}=.024, .224$, mean level $\mathrm{b}=.163, \mathrm{CI}=.100, .240$ and high-level $\mathrm{b}=.187$, $\mathrm{CI}=.100, .296$ ). However, results reveal that the moderated mediation effect was much stronger at the higher level of the perceived corporate image (1 standard deviation above the mean) than at the lower level and the mean level ( 1 standard deviation below the mean and at the mean level). The findings are further illustrated in Figure 5. 


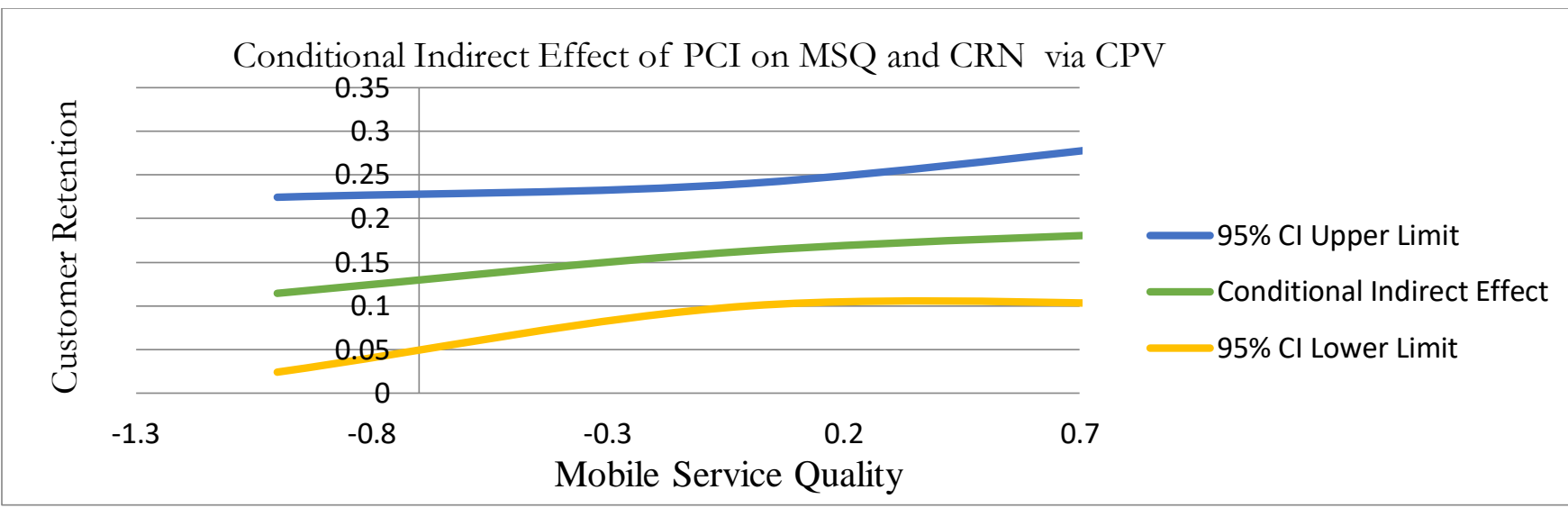

Figure 5 - Moderation of Corporate image on Mobile service quality and Customer retention via Customer Perceived Value

\section{Discussion}

The goal of this study is fourfold; first was to explore the direct effects of the study variables on customer retention in the Kenyan banking industry, secondly was to determine the mediating effect of customer perceived value, thirdly was explore the moderating effect of corporate image, the fourth and final goal was to determine the moderating effect of corporate image on the indirect link between mobile banking service quality and customer retention via customer perceived value.

We postulated that high mobile banking service quality, customer-perceived service value, and a strong corporate image directly affect customer retention. The results support the hypothesis. The study established that mobile banking service quality has a positive and significant effect on customer retention. Literature on service quality indicates that the greater the quality perceived, the stronger the relationship commitment and repurchase intentions (Srivastava and Sharma, 2013). Furthermore, Surendra (2015) established that mobile banking service quality is one of the critical success factors influencing a bank's competitiveness. The findings are supported by earlier findings by Ranaweera and Neely (2003), who established a positive association between perceived service quality and customer repurchasing or retention. We, therefore, argue in this study, customers consider the quality of the mobile banking services when evaluating the service provider to decide whether to continue using the service or not. Hence, the higher the service quality, the higher the retention rates. On the contrary, the lower the quality of the mobile banking services, the higher the defection rates or customer churn.

The study findings also reveal a positive and significant effect of customer perceived value on customer retention. These findings support previous research in customer relationship management which links customer perceived value and customer retention. For instance, Milan et al., (2015) established that clients in the corporate market are more willing to keep relationships with existing suppliers if they are being attended to with elevated value. The findings are also supported by the ideas of Carlos et al.,(2006), who suggested that a relationship journey between a bank and its customer where both parties hope to obtain certain advantages and benefits (value) through the working and development of the relationship, the advantages that the service provider obtains from the relationship are linked to the loyalty of the customer. We argue in this study that customers engage in a matching process in establishing value for their money. Hence, where services match or exceed the customers' perceived value expectation, they are influenced to make repeat purchases.

Moreover, the findings of this study confirm that customer perceived value mediates the link between mobile service quality and customer retention. We argue in this study that when a bank offers superior quality of mobile banking services, it improves the customer perceived value and which will in turn influence patronage of the 
m-banking services. This shows how critical it is for mobile banking service providers to offer their customers the right information and quality $\mathrm{m}$-banking services via $\mathrm{m}$-banking channels since this contributes to high perceived value in their clients' minds. This influences their decisions on whether to stay with or switch from the $\mathrm{m}$-banking service provider.

Another important finding was that perceived corporate image has a positive moderating effect on the relationship between mobile banking service quality and customer retention. Indeed, we postulated that customer retention will be higher when the firm's perceived corporate image is high. We argue that consumer behavior is largely guided by perceptions, such that when a firm's corporate image is good, customer perceived value and service quality will be high and which consequently will lead an enhanced customer retention.

Finally, our findings confirm the fourth hypothesis perceived corporate image moderates the indirect relationship between mobile banking service quality and customer retention via customer perceived value in such a way that the relationship is significant at all the three levels of perceived corporate image (low level b $=.114, \mathrm{CI}=.024, .224$, mean level $\mathrm{b}=.163, \mathrm{CI}=.100, .240$ and high level $\mathrm{b}=.187, \mathrm{CI}=.100, .296)$. However, results reveal that the moderated mediation effect was much stronger at the higher level of perceived corporate image ( 1 standard deviation above the mean) than at the lower level and at the mean level (1 standard deviation below the mean and at the mean level.

\section{Conclusion}

This study provides an important research model in understanding the role of mobile banking service quality, customer perceived value, and perceived corporate image in influencing consumers of mobile banking services to commit to patronizing the bank consistently in the future. Based on this study results, it has been clarified that mobile banking service quality, customer perceived value, and perceived corporate image are the powerful drives of customer retention. Moreover, this study concludes that mobile banking service quality influences the customer's perceived value, enhancing customer retention. Additionally, the study reveals that customers' perception of the banks' corporate image influences their attitudes towards the bank and how they commit to patronizing mobile banking services consistently in the future. The implication of this is that the customer decisions to commit to staying with the bank is partly depend on their perceptions towards the banks' corporate image, quality of the banks' mobile banking services, and the customer's perceived value, hence the variables used in this study plays a critical role in the customer's decision making the process.

\section{Theoretical and Managerial Implications}

This study carries several theoretical contributions to the customer relationship management and consumer behavior literature from a theoretical perspective. First, this study adopted a comprehensive moderated mediated model to investigate the effects of mobile banking service quality, customer perceived value, and corporate image on customer retention. Moderated mediated models have not yet been featured in the extant services marketing or bank marketing literature for enhancing customer retention to mobile banking services via customer perceived value and perceived corporate image. Therefore, the study findings provide new insights that the effects of mobile banking service quality on customer retention are mediated by customer perceived value. These mediation effects are moderated by perceived corporate image. The findings further contribute to knowledge through the mediation and moderation effects models.

Second, it is worthy to note that this study was carried out in Kenya, a developing country in the eastern part of Africa. In Kenya and other developing countries, mobile banking technologies are at the initial stages of the product life cycle and experiencing enormous e-banking growth in mobile banking services. This notwithstanding, insufficient research exists surrounding mobile banking services and customer retention in the 
Kenyan context. Hence, this study provides valuable insights into the customer retention and mobile banking services research literature.

Thirdly, the study findings support all the theories that were adopted. The study used the leaky bucket theory developed by Ehrenberg, (1988) to emphasize the significance of maintaining a consistent base of customers for a business to operate at a profitable level while recognizing that customer acquisition was still important to replace the customers who may have switched (leaked) for whatever reasons. The theory postulates that a company can only succeed in business if it restricts the flow of old customers and both a flow of new customers. The study also used the customer value/retention model developed by Weinstein, (2002) to theoretically argue a relationship between service quality, customer perceived value, and customer retention. Finally, the M-SQUAL model designed by Surendra, (2015), was used to theoretically argue a relationship between mobile banking service dimensions and customer retention. The study, therefore, contributes to understanding these theories in the mobile banking service context.

The study also supports prior literature and recent advances in the general marketing and consumer behavior literature, which have all reported that service quality, perceived customer value and perceived corporate image greatly influences consumer behaviour. The most important contribution is evident in the complex moderated mediation model used in this study. Previous studies have mainly focused on simple main effects and mostly on the bi-variate nature ignoring the accepted fact that consumer decision making is a complex and comprehensive process. Simple models, therefore, fail to capture the complex nature of consumer decisionmaking. This study, therefore, breaks into this new ground of embracing a more complex model of consumer behavior.

Overall, the findings are insightful and contribute to the services marketing and customer behavior literature, especially in the banking services marketing context. This study is useful to the researchers who are interested in furthering their understanding of mobile banking services.

\section{Implications for Future Research}

This study has contributed to and enriched the body of knowledge on the complex nature of consumer decisionmaking processes. However, it has opened up gaps that future studies may pursue to enhance knowledge in this area. First, the study used quantitative data to analyze its findings; future studies may consider incorporating quantitative and qualitative data as this may reveal other aspects that enhance customer retention than those mentioned in the current study. In addition, the study adopted a cross-sectional research design as all data were collected at one point in time; which makes it difficult to generalize the findings and account for changes that may occur in the mobile banking technologies, which may tilt the customer's attitude and perception of quality, value, and image. Therefore, future research may consider using longitudinal designs to seek more evidence for the assumptions made in this study. Furthermore, data collected for this study was from only one region of the Republic of Kenya. Future studies should consider testing the present model on other populations and a wider area, and a large target population to validate our findings.

Funding: This research received no external funding

Conflicts of Interest: The authors declare no conflict of interest.

\section{References}

Ahmad, R., \& Buttle, F. (2002). Customer retention management: A reflection of theory and practice. Marketing Intelligence \& Planning, 20(3), 149-161.

Al-Hawari, M. (2006). The effect of automated service quality on bank financial performance and the mediating role of customer retention. Journal of Financial Services Marketing, 10(3), 228-243. 
Angel Moliner Tena, M., Carlos Fandos Roig, J., Llorens Monzonis, J., \& Sanchez Garcia, J. (2006). Customer perceived value in banking services. International Journal of Bank Marketing, 24(5), 266-283. https://doi.org/10.1108/02652320610681729

Carlos, J., Sanchez, J., Angel, M. M., \& Llorens, J. (2006). Customer perceived value in banking services. International Journal of Bank Marketing, 24(5), 266-283.

Chen, H., \& Zhu, Y. (2012). Service fairness and customer satisfaction in internet banking: Exploring the mediating effects of trust and customer value. Internet Research, 22(4), 482-498. https://doi.org/10.1108/10662241211251006

Cronin Jr, J. J., Brady, M. K., \& Hult, G. T. M. (2000). Assessing the effects of quality, value, and customer satisfaction on consumer behavioral intentions in service environments. Journal of Retailing, 76(2), 193-218.

Ehrenberg, A. S. C. (1988). Repeat-buying: Facts, theory, and applications (New ed). Griffin ; Oxford University Press.

Evans, G. (2002). Measuring and managing customer value. Work Study, 51(3), 134-139. https://doi.org/10.1108/00438020210424262

Gautam, V. (2011). Investigating the Moderating Role of Corporate Image in the Relationship between Perceived Justice and Recovery Satisfaction: Evidence from Indian Aviation Industry. 1, 12.

Groth, J. C., \& Dye, R. T. (1999). Service quality: Perceived value, expectations, shortfalls, and bonuses. Managing Service Quality: An International Journal, 9(4), 274-286. https://doi.org/10.1108/09604529910273229

Hanaysha, J. R. (2018). Customer retention and the mediating role of perceived value in retail industry. World Journal of Entrepreneurship, Management and Sustainable Development, 14(1), 2-24. https://doi.org/10.1108/WJEMSD-06-2017-0035

Hapsari, R., Clemes, M., \& Dean, D. (2016). The mediating role of perceived value on the relationship between service quality and customer satisfaction: Evidence from Indonesian airline passengers. Procedia Economics and Finance, 35(12), 388-395.

Kassim, N. M., \& Souiden, N. (2007). Customer retention measurement in the UAE banking sector. Journal of Financial Services Marketing, 11(3), 217-228.

Kaur, H., \& Soch, H. (2013). Mediating roles of commitment and corporate image in the formation of customer loyalty. Journal of Indian Business Research, 5(1), 33-51.

Keshavarz, Y., \& Jamshidi, D. (2018). Service quality evaluation and the mediating role of perceived value and customer satisfaction in customer loyalty. International Journal of Tourism Cities, 4(2), 220-244. https://doi.org/10.1108/IJTC-09-2017-0044

Ladhari, R., Souiden, N., \& Ladhari, I. (2011). Determinants of loyalty and recommendation: The role of perceived service quality, emotional satisfaction and image. Journal of Financial Services Marketing, 16(2), 111-124.

MacKinnon, D. P., Cheong, J., \& Pirlott, A. G. (2012). Statistical mediation analysis. ResearchGate. https://www.researchgate.net/publication/281339075_Statistical_mediation_analysis

Manali, M. (2014). Strategic benefits and challenges of mobile banking in Kenyan commercial banks. 65.

Milan, G. S., Eberle, L., \& Bebber, S. (2015). Perceived value, reputation, trust, and switching costs as determinants of customer retention. Journal of Relationship Marketing, 14(2), 109-123. 
MoyoTalak, M. (2013). Customer Retention Strategies by mobile phone Service providers in Zimbabwe: Case of Masvingo City. IOSR Journal of Business and Management, 9(4), 71-82. https://doi.org/10.9790/487X-0947182

Nguyen, N., \& LeBlanc, G. (1998). The mediating role of corporate image on customers' retention decisions: An investigation in financial services. International Journal of Bank Marketing, 16(2), 52-65.

Nguyen, N., \& Leblanc, G. (2001). Corporate image and corporate reputation in customers' retention decisions in services. Journal of Retailing and Consumer Services, 8(4), 227-236.

Rahman, D. A., Hasan, M., \& Mia, A. (2017). Mobile Banking Service Quality and Customer Satisfaction in Bangladesh: An Analysis. 45(2), 8.

Ranaweera, C., \& Neely, A. (2003). Some moderating effects on the service quality-customer retention link. International Journal of Operations \& Production Management, 23(2), 230-248. https://doi.org/10.1108/01443570310458474

Siu, N. Y.-M., Zhang, T. J.-F., \& Yau, C.-Y. J. (2013). The roles of justice and customer satisfaction in customer retention: A lesson from service recovery. Journal of Business Ethics, 114(4), 675-686.

Srivastava, K., \& Sharma, N. K. (2013). Service Quality, Corporate Brand Image, and Switching Behavior: The Mediating Role of Customer Satisfaction and Repurchase Intention. Services Marketing Quarterly, 34(4), 274-291.

Surendra, M. (2015). Exploring Mobile Banking Service Quality Dimensions for Public and Private Sector Banks in Indore District of Madhya Pradesh. 3(1), 10.

Sweeney, J. C., \& Soutar, G. N. (2001). Consumer perceived value: The development of a multiple item scale. Journal of Retailing, 77(2), 203-220.

Tamuliene, V., \& Gabryte, I. (2014). Factors Influencing Customer Retention: Case Study of Lithuanian Mobile Operators. Procedia - Social and Behavioral Sciences, 156, 447-451. https://doi.org/10.1016/j.sbspro.2014.11.219

uniRankTM. (2020). Universities in Kenya | Higher Education in Kenya. https://www.4icu.org/ke/universities/

Weinstein, A. (2002). Customer retention: A usage segmentation and customer value approach. Journal of Targeting, Measurement and Analysis for Marketing, 10(3), 259-268.

Yang, Z., \& Peterson, R. T. (2004). Customer perceived value, satisfaction, and loyalty: The role of switching costs. Psychology \& Marketing, 21(10), 799-822.

Zeithaml, V. A. (1988). Consumer perceptions of price, quality, and value: A means-end model and synthesis of evidence. Journal of Marketing, 52(3), 2-22. 